Available online at : http://journal.unj.ac.id/unj/index.php/gjik

Gladi Jurnal Ilmu Keolahragaan 07 (02) 2013, 746-764

Permalink/DOI: https://doi.org/10.21009/GJIK.072.02

\title{
CEDERA OLAHRAGA PADA ATLET PROVINSI DKI JAKARTA (PENGARUH PEMAHAMAN PELATIH, SARANA - PRASARANA OLAHRAGA DAN METODE LATIHAN TERHADAP TERJADINYA CEDERA OLAHRAGA)
}

\begin{abstract}
Junaidi $^{1}$
Abstract, The objectives of this research are to obtain information the effect of coach comprehension, sport facilities and training method on sport injuries at the Training Centres Athletes - National Sport Committee of DKI Jakarta Province periode 2009 - 2012. This study was conducted at DKI Jakarta Province by using survey method with path analysis applied in testing hypothesis. The number of 55 subdivisions as a sample is selected random sampling. The research findings are: (1) There is a non-direct effect of coach comprehension on sport injuries; (2) There is a non-direct effect of sport facilities on sport injuries; (3) There is a direct effect of training method on sport injuries; (4) There is a direct effect of coach comprehension on training method; (5) There is a direct effect of sport facilities on training method; (6) There is an effect of coach comprehension on sport injuries through the training method; (7) There is an effect of sport facilities on sport injuries through the training method.
\end{abstract}

Key words; Coach Comprehension, Sport Facilities, Training Method and Sport Injuries.

${ }^{1}$ Junaidi adalah Dosen Tetap Jurusan Kepelatihan FIK Universitas Negeri Jakarta 


\title{
PENDAHULUAN
}

\begin{abstract}
Pemerintah Provinsi DKI Jakarta melalui Komite Olahraga Nasional Indonesia (KONI) Provinsi DKI Jakarta secara konsisten terus berupaya meningkatkan prestasi atlet Provinsi DKI Jakarta. Salah satu upaya Pemerintah Provinsi DKI Jakarta untuk meningkatkan prestasi atlet Provinsi DKI Jakarta adalah dengan melaksanakan Pemusatan Latihan Daerah (Pelatda). Pelatda diikuti 459 atlet senior dan 185 atlet junior, berlangsung mulai tanggal 1 Mei 2009 sampai tanggal 8
\end{abstract} September 2012.

Pemilihan atlet yang akan masuk Pelatda berdasarkan tiga kriteria utama, yaitu : 1) Atlet senior yang mendapat medali di PON Kalimantan Timur tahun 2008 atau atlet yang mendapat medali di Kejuaraan Nasional tahun 2008/2009, 2) Atlet junior potensial, dan 3) Sehat fisik dan rohani.

Meskipun sudah dibuat kriteria tersebut, dalam pelaksanaannya banyak mendapat hambatan terutama pada kriteria sehat fisik dan rohani, karena banyak atlet yang mengalami cedera. Oleh sebab itu Peneliti tertarik untuk meneliti faktor-faktor yang berhubungan dengan terjadinya cedera olahraga pada atlet Provinsi DKI Jakarta

Berdasarkan latar belakang masalah, penelitian ini dirumuskan sebagai berikut : 1 . Apakah terdapat pengaruh pemahaman pelatih terhadap metode latihan. 2. Apakah terdapat pengaruh sarana/prasarana olahraga terhadap metode latihan. 3. Apakah terdapat pengaruh metode latihan terhadap cedera olahraga. 4. Apakah terdapat pengaruh pemahaman pelatih terhadap cedera olahraga. 5. Apakah terdapat pengaruh sarana/prasarana olahraga terhadap cedera olahraga. 6. Apakah terdapat pengaruh tidak langsung antara pemahaman pelatih terhadap cedera olahraga melalui metode latihan. 7. Apakah terdapat pengaruh tidak langsung sarana dan prasarana olahraga terhadap terjadinya cedera olahraga melalui metode latihan 


\section{KAJIAN TEORITIK}

\section{Cedera Olahraga}

Cedera olahraga adalah cedera yang terjadi pada sistem muskuloskeletal atau sistem lain sehingga dapat mempengaruhi sistem muskuloskeletal, terjadi baik pada waktu latihan, pertandingan, maupun sesudahnya dengan indikator yaitu cedera sangat berat, cedera berat, cedera sedang, cedera ringan, dan cedera sangat ringan. Faktor-faktor penyebab terjadinya cedera olahraga antara lain: 1) faktor eksogen, yang terdiri dari: a). cara pemberian beban latihan yang salah, pemanasan yang salah, cara latihan yang salah, latihan yang tidak teratur, b). penggunaan material yang salah, c). fasilitas latihan yang tidak memadai, d). jenis olahraga, terutama pada olahraga beladiri. 2). Faktor endogen, misalnya; faktor disposisi keluarga, kondisi umum buruk, penyakit infeksi, kelainan sistem muskuloskeletal, usia, dan cara bergerak yang tidak fisiologik.

Dalam banyak kasus, penyebab cedera karena terlalu sering menggunakan bagian tubuh tertentu saat berpartisipasi dalam suatu kegiatan tertentu, contoh; cedera pada lutut pelari umumnya terkait dengan aktivitas lari dan tennis elbow merupakan cedera stres berulang pada siku, meskipun tidak selalu terjadi pada pemain tenis.

\section{Pemahaman Pelatih.}

Pemahaman merupakan proses psikologi yang berhubungan dengan suatu konsep, memberikan reaksi yang tepat terhadap suatu obyek. Pemahaman kognitif memiliki perspektif bahwa seseorang memproses informasi yang diberikan melalui upayanya mengorganisir, menyimpan, dan kemudian menemukan hubungan antara pengetahuan yang baru dengan pengetahuan yang telah ada. Model ini menekankan pada bagaimana informasi diproses.

Pelatih menurut menurut Pate Roteila Mc Clenaghan adalah seorang profesional yang tugasnya membantu olahragawan dan tim dalam memperbaiki penampilan olahraga. Dalam prinsip-prinsip pelatihan, Harsono mengungkapkan 
bahwa "pelatih adalah orang yang membantu atlet dalam meningkatkan prestasi olahraganya

Dari uraian tersebut dapat disintesiskan bahwa pemahaman pelatih adalah pemahaman kognitif yang dimiliki seorang pelatih dalam memproses informasi yang diberikan melalui upaya penangkapan makna, pengingatan, menyimpan, penilaian, dan penalaran, mengorganisir, kemudian menemukan hubungan antara pengetahuan yang baru dengan pengetahuan yang telah ada, dengan indikator yaitu pemahaman tentang pencegahan cedera, pemahaman tentang warming-up dan cooling-down, aspek kebugaran dan pemahaman tentang nutrisi, dan pemahaman tentang penanganan cedera.

\section{Sarana dan Prasarana Olahraga}

Sarana dan prasarana olahraga adalah sumber daya pendukung yang terdiri dari segala bentuk dan jenis peralatan serta perlengkapan yang digunakan dalam kegiatan olahraga meliputi semua lapangan dan bangunan olahraga beserta perlengkapan dengan indikator yaitu prinsip dasar prasarana, kelengkapan prasarana, kuantitas sarana, dan kualitas sarana.

Sebelum merencanakan pembangunan sarana prasarana olahraga, penting mempertimbangkan landasan objektif mengenai kebutuhan prasarana tersebut. Untuk itu perencanaannya harus memenuhi beberapa prinsip, antara lain: 1) Sarana dan prasarana olahraga harus masuk dalam rencana induk dari suatu institusi, 2) Tipe, lokasi, dimensi wilayah sarana prasarana olahraga sebaiknya dibangun berkaitan dengan fasilitas yang sudah ada, 3) Sarana prasarana olahraga harus memenuhi peraturan setempat dan standar yang berlaku, 4) Sarana prasarana olahraga harus dibangun dan direncanakan secara hati-hati dan terorganisir, 5) Sarana prasarana olahraga harus memenuhi standard untuk penonton, 6) Sarana prasarana harus memenuhi tingkat kebutuhan atlet, 7) Sarana prasarana olahraga dibangun dengan mempertimbangkan faktor keselamatan bagi atlet, 8) Sarana prasarana olahraga dibangun dengan mempertimbangkan faktor kesehatan dan kenyamanan atlet, 9) jenis dan jumlah peralatan olahraga harus cukup sesuai kebutuhan, 10) Semua peralatan 
harus mempunyai kualitas standar untuk mencapai prestasi, 11) Semua peralatan harus mempunyai kualitas standar untuk keselamatan dan nyaman digunakan.

Dari uraian diatas dapat diambil kesimpulan bahwa bila seorang pelatih memberikan latihan kepada atletnya dengan sarana dan prasarana yang kurang memadai dapat menyebabkan terjadinya cedera pada atletnya, baik selama latihan ataupun sesudahnya

\section{Metode Latihan}

Metode latihan adalah cara atau prosedur dalam menjalani suatu aktifitas olahraga yang sistematik menurut prinsip-prinsip latihan yang mengarah kepada ciriciri fungsi fisiologis dan psikologis manusia untuk mencapai sasaran yang telah ditentukan dengan indikator yaitu prinsip latihan, variabel latihan, periodisasi Latihan, dan latihan penguatan serta daya tahan.

Salah satu ciri pelatih yang baik adalah pandai memilih atau menciptakan metode latihan yang efektif dan efisien untuk mencapai sasaran latihan. Pelatih dituntut menguasai ilmu, memiliki jiwa seni yang tinggi serta seorang praktisi untuk menerapkan teori dan metodelogi ilmu pelatihan. Metode latihan dapat efektif dan efisien juga tergantung dari beberapa faktor antara lain; pelatih, atlet, alat dan fasilitas latihan, tujuan latihan, waktu dan lingkungan berlatih

Prinsip latihan yang harus dikuasai oleh pelatih dalam memberi pelatihan kepada atlet, sebagai berikut:1) Prinsip perkembangan multilateral, 2) Prinsip spesialisasi, 3) Prinsip individualisasi, 4) Prinsip bervariasi dalam latihan, 5) Prinsip model latihan, 6) Prinsip beban berlebihan (overload), 7) Latihan harus sepanjang tahun terseling atau kontinyuitas, 8) Kenaikan beban latihan teratur dari sedikit demi sedikit, 9) Prinsip Interval, 10) Prinsip repetisi, 11) Prinsip nutrisium, 12) Prinsip recovery, 13) Prinsip reversibility, 14) Prinsip pemanasan tubuh, 15) Prinsip berpikir positif, 16) prinsip intensitas latihan, 17) Prinsip kualitas latihan, 18) Prinsip memperbaiki kesalahan, 19) Prinsip menetapkan sasaran, dan 20) Prinsip detraining. 


\section{Kerangka Teoretik}

Mengacu pada kajian teoretik yang telah diuraikan sebelumnya, maka keterkaitan antar variabel penelitian dapat diuraikan sebagai berikut:

\section{Pengaruh pemahaman pelatih terhadap metode latihan}

Pemahaman pelatih adalah pemahaman kognitif yang dimiliki seorang pelatih dalam memproses informasi yang diberikan melalui upaya penangkapan makna, pengingatan, menyimpan, penilaian, dan penalaran, mengorganisir, kemudian menemukan hubungan antara pengetahuan yang baru dengan pengetahuan yang telah ada. Pemahaman pelatih yang dimaksud dalam bidang pencegahan dan penanganan cedera olahraga. Dengan kata lain setiap kali pelatih memberi latihan kepada atletnya, pelatih harus memahami segala faktor penyebab terjadinya cedera yang berhubungan dengan cara latihan yang diberikan.

\section{Pengaruh sarana dan prasarana olahraga terhadap metode latihan}

Salah satu ciri pelatih yang baik adalah pandai memilih atau menciptakan metode latihan yang efektif dan efisien untuk mencapai sasaran latihan. Pelatih dituntut menguasai ilmu, memiliki jiwa seni yang tinggi serta seorang praktisi untuk menerapkan teori dan metodologi ilmu pelatihan. Metode latihan dapat efektif dan efisien juga tergantung dari beberapa faktor antara lain, pelatih, atlet, alat dan sarana dan prasana latihan, tujuan latihan, waktu dan lingkungan berlatih. Sarana dan prasarana yang tersedia sangat mempengaruhi cara seorang pelatih dalam memberi metode latihan. Sarana dan prasarana yang kurang memadai bukan saja menjadikan suatu metode latihan tidak efektif, juga dapat mempermudah terjadinya cedera.

\section{Pengaruh metode latihan terhadap terjadinya cedera olahraga}

Faktor yang paling sering menjadi penyebab terjadinya cedera olahraga adalah faktor metode latihan. Metode latihan yang salah ini misalnya cara pemberian beban latihan yang salah, tidak sesuai dengan prinsip latihan, yaitu prinsip kenaikan beban latihan teratur dari sedikit demi sedikit, maka menaikkan beban latihan yang tiba-tiba dapat menyebabkan tubuh tidak mampu menerima beban yang diberikan dan akhirnya menimbulkan cedea. 


\section{Pengaruh langsung pemahaman pelatih terhadap terjadinya cedera olahraga.}

Atlet .juga dapat mengalami cedera tanpa melewati proses latihan, misalnya, bila pelatih tidak memahami tentang pola hidup sehat atau Istirahat yang tidak cukup sesudah melakukan latihan yang berat dapat menimbulkan cedera.

\section{Pengaruh langsung sarana/prasarana olahraga terhadap terjadinya cedera}

Sarana/prasarana yang kurang memadai dapat secara langsung menyebakan terjadinya cedera olahraga, misalnya penggunaan ruang tidur atau ruang ganti yang terlalu panas dapat menyebabkan dehidrasi.

\section{Pengaruh pemahaman pelatih terhadap terjadinya cedera olahraga melalui metode latihan..}

Dalam memberi pelatihan kepada atlet, seorang pelatih harus memahami aspek-aspek pemahaman apa yang perlu diperhatikan. Pemahaman tentang pencegahan dan penangan cedera yang kurang memadai selama melatih dapat mengakibatkan terjadinya cedera olahraga.

\section{Pengaruh sarana dan prasarana olahraga terhadap terjadinya cedera olahraga melalui metode latihan}

Peralatan olahraga yang tidak memenuhi persyaratan, misalnya penggunaan raket tenis yang ukurannya tidak sesuai dengan masing-masing individu, penggunaan sepatu yang sudah usang, penggunaan alat proteksi yang tidak memadai , semuanya akan memudahkan terjadinya cedera.

\section{Hipotesis Penelitian}

Berdasarkan kerangka teori dan kerangka berpikir setiap variabel penelitian yang telah dikemukakan di atas maka dalam peneltian ini dapat dirumuskan pengajuan hipotesis sebagai berikut: 1. Terdapat pengaruh langsung pemahaman pelatih terhadap metode latihan. 2. Terdapat pengaruh langsung sarana dan prasarana olahraga terhadap metode latihan. 3. Terdapat pengaruh metode latihan terhadap terjadinya cedera olahraga. 4. Terdapat pengaruh langsung pemahaman pelatih 
terhadap terjadinya cedera olahraga. 5. Terdapat pengaruh langsung sarana/prasarana olahraga terhadap terjadinya cedera olahraga. 6. Terdapat pengaruh tidak langsung pemahaman pelatih terhadap terjadinya cedera olahraga melalui metode latihan. 7 . Terdapat pengaruh tidak langsung sarana dan prasarana olahraga terhadap terjadinya cedera olahraga melalui metode latihan.

\section{METODOLOGI PENELITIAN}

Penelitian ini dilaksanakan di setiap cabang olahraga. Waktu pelaksanaan penelitian: tahap pertama uji coba instrumen penelitian dilakukan pada tanggal 4 Agustus 2011 sampai dengan tanggal 25 November 2011, Tahap kedua penelitian dilakukan pada tanggal 1 Desember 2011 sampai dengan 29 Februari 2012, Data yang terkumpul kemudian dilakukan pengolahan data, proses penulisan disertasi, hingga penarikan kesimpulan dan penyelesaian disertasi secara keseluruhan.

Metode penelitian yang digunakan dalam penelitian ini adalah metode deskriptif dengan teknik survey, yaitu dengan tehnik pengajuan pertanyaan atau kuesioner. Teknik analisis menggunakan pendekatan analisis jalur (path analysis). Variabel yang dikaji terdiri dari empat variabel yang terdiri dari tiga variabel bebas (eksogen) dan satu variabel terikat (endogen).Variabel eksogen terdiri dari pemahaman pelatih (X1), sarana/prasarana olahraga(X2) dan metode latihan (X3).Variabel endogen terdiri dari cedera olahraga (Y).

Pola keterkaitan antar variabel penelitian terlihat pada gambar berikut ini:

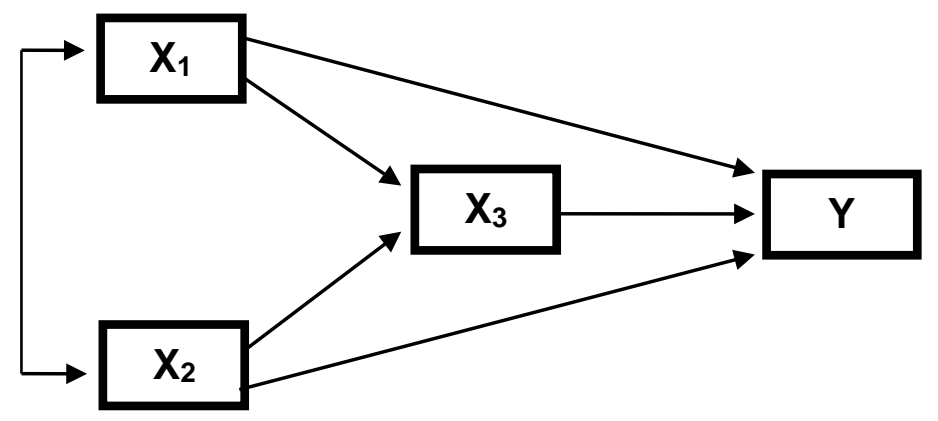

Gambar 1 : Model Hipotetik Kausalitas Antar Variabel 
Keterangan :

$\mathrm{X}_{1}$ :Pemahaman Pelatih, $\mathrm{X}_{2}$ : Sarana dan Prasarana Olahraga, $\mathrm{X}_{3}$ : Metode Latihan Y : Cedera Olahraga

Dalam penelitian ini yang digunakan sebagai populasi sasaran (target population) adalah seluruh cabang olahraga Pelatda KONI Provinsi DKI Jakarta Sedangkan pengambilan sampel dilakukan dengan menggunakan tehnik total sampling sebanyak 55 cabang olahraga/subcabang olahraga. Tehnik analisis data secara analisis deskriptif dan analisis inferensial dengan analisis jalur.

Data yang disajikan setelah diolah dari data mentah dengan menggunakan metode statistik deskriptif, yaitu nilai maksimum, nilai minimum, rentang, rata-rata, simpangan baku dan varians. Rangkuman hasil perhitungan statistik sebagai berikut:

Tabel 1. Rangkuman Hasil Penelitian

\begin{tabular}{|c|c|c|c|c|}
\hline \multirow{2}{*}{ STATISTIK } & \multicolumn{4}{|c|}{ VARIABEL } \\
\cline { 2 - 5 } & $\mathbf{X}_{\mathbf{1}}$ & $\mathbf{X}_{\mathbf{2}}$ & $\mathbf{X}_{\mathbf{3}}$ & $\mathbf{Y}$ \\
\hline Jumlah Sampel (n) & 55 & 55 & 55 & 55 \\
\hline Nilai Maksimum & 129 & 134 & 104 & 228 \\
\hline Nilai Minimum & 86 & 90 & 59 & 63 \\
\hline Rentang & 43 & 44 & 45 & 165 \\
\hline Rata-rata $(X)$ & 104,93 & 113,45 & 82,31 & 159,62 \\
\hline Simpangan Baku $(s)$ & 10,72 & 10,99 & 9,92 & 49,10 \\
\hline Varians $(s 2)$ & 114,85 & 120,77 & 98,44 & 2410,72 \\
\hline
\end{tabular}

Keterangan:

$\mathrm{X}_{1} \quad$ : Pemahaman Pelatih , $\mathrm{X}_{2}$ : Sarana dan Prasarana Olahraga,

$\mathrm{X}_{3} \quad$ : Metode Latihan, $\mathrm{Y}$ : Cedera Olahraga 
1. Cedera olahraga yang terjadi pada atlet Pelatda 2009-2012 (Y)

Tabel 2 . Daftar Distribusi Frekuensi Skor Cedera Olahraga

\begin{tabular}{|c|c|c|c|c|}
\hline \multirow{2}{*}{ No. } & \multirow{2}{*}{ Kelas Interval } & Absolut & Relatif (\%) & \begin{tabular}{c}
$|c|$ \\
\cline { 3 - 5 }
\end{tabular} \\
\cline { 3 - 5 } & & & & Krekuensi \\
\hline 1 & $63-86$ & 5 & 9,09 & 9,09 \\
\hline 2 & $87-110$ & 5 & 9,09 & 18,18 \\
\hline 3 & $111-134$ & 9 & 16,36 & 34,55 \\
\hline 4 & $135-158$ & 8 & 14,55 & 49,09 \\
\hline 5 & $159-182$ & 4 & 7,27 & 56,36 \\
\hline 6 & $183-205$ & 11 & 20,00 & 76,36 \\
\hline 7 & $206-229$ & 13 & 23,64 & 100,00 \\
\hline & Jumlah & 55 & 100 & \\
\hline
\end{tabular}

Dari 55 orang sampel penelitian, jika hasil masing-masing responden dibandingkan dengan rata-ratanya, ternyata yang mendapatkan cedera olahraga (Y) di atas kelompok rata-rata sebanyak 24 orang (43,64\%), berada di bawah kelompok rata-rata sebanyak 27 orang (49,07\%), dan 4 orang $(7,27 \%)$ berada di pada kelompok rata-rata.

2. Pemahaman pelatih dalam pencegahan dan penanganan cedera $\left(X_{1}\right)$

Tabel 3. Distribusi Frekuensi Skor Pemahaman Pelatih

\begin{tabular}{|c|c|c|c|c|}
\hline \multirow{2}{*}{ No. } & \multirow{2}{*}{ Kelas Interval } & Absolut & Relatif (\%) & $\begin{array}{c}\text { Kumulatif } \\
\mathbf{( \% )}\end{array}$ \\
\cline { 3 - 5 } & & 7 & 12,73 & 12,73 \\
\hline 1 & $86-93$ & 19 & 34,55 & 47,27 \\
\hline 2 & $94-101$ & 11 & 20,00 & 67,27 \\
\hline 3 & $102-109$ & 10 & 18,18 & 85,45 \\
\hline 4 & $110-117$ & & & \\
\hline
\end{tabular}




\begin{tabular}{|c|c|c|c|c|}
\hline 5 & $118-125$ & 5 & 9,09 & 92,73 \\
\hline 6 & $126-133$ & 3 & 5,45 & 100,00 \\
\hline & Jumlah & 55 & 100 & \\
\hline
\end{tabular}

Berdasarkan data dari 55 orang sampel penelitian, jika hasil masing-masing responden dibandingkan dengan rata-ratanya, ternyata yang mendapatkan skor pemahaman pelatih $\left(\mathrm{X}_{1}\right)$ di atas rata-rata kelompok sebanyak 18 orang (32,73\%), berada di bawah rata-rata kelompok sebanyak 26 orang (47,27\%), dan 11 orang (20,00\%) berada pada kelompok rata-rata.

\section{Sarana dan prasarana olahraga $\left(\mathrm{X}_{2}\right)$}

Tabel 4. Distribusi Frekuensi Skor Sarana/Prasarana Olahraga

\begin{tabular}{|c|c|c|c|c|}
\hline \multirow{2}{*}{ No. } & \multirow{2}{*}{ Kelas Interval } & Absolut & Relatif (\%) & $\begin{array}{c}\text { Kumulatif } \\
\text { (\%) }\end{array}$ \\
\cline { 3 - 5 } & & 6 & 10,91 & 10,91 \\
\hline 1 & $90-97$ & 5 & 9,09 & 20,00 \\
\hline 2 & $98-105$ & 16 & 29,09 & 49,09 \\
\hline 3 & $106-113$ & 15 & 27,27 & 76,36 \\
\hline 4 & $114-121$ & 11 & 20,00 & 96,36 \\
\hline 5 & $122-129$ & 2 & 3,64 & 100,00 \\
\hline 6 & $130-137$ & 55 & 100 & \\
\hline & Jumlah & & \multicolumn{3}{|c|}{ Frekuensi } \\
\hline
\end{tabular}

Berdasarkan data dari 55 orang sampel penelitian, jika hasil masing- masing responden dibandingkan dengan rata-ratanya, ternyata yang mendapatkan skor sarana dan prasarana olahraga $\left(\mathrm{X}_{2}\right)$ di atas rata-rata kelompok sebanyak 13 orang (23,64\%), berada di bawah rata-rata kelompok sebanyak 27 orang (49,09\%), dan 15 orang (27,27\%) berada pada kelompok rata-rata. 


\section{Metode latihan $\left(X_{3}\right)$}

Tabel 5. Daftar Distribusi Frekuensi Skor Metode Latihan

\begin{tabular}{|c|c|c|c|c|}
\hline \multirow{2}{*}{ No. } & \multirow{2}{*}{ Kelas Interval } & Fbsolut & Relatif (\%) & $\begin{array}{c}\text { Kumulatif } \\
\text { (\%) }\end{array}$ \\
\cline { 3 - 5 } & & Abekuensi \\
\hline 1 & $59-66$ & 3 & 5,45 & 5,45 \\
\hline 2 & $67-73$ & 3 & 5,45 & 10,91 \\
\hline 3 & $74-81$ & 23 & 41,82 & 52,73 \\
\hline 4 & $82-89$ & 14 & 25,45 & 78,18 \\
\hline 5 & $90-97$ & 6 & 10,91 & 89,09 \\
\hline 6 & $98-105$ & 6 & 10,91 & 100,00 \\
\hline & Jumlah & 55 & 100 & \\
\hline
\end{tabular}

Berdasarkan data dari 55 orang sampel penelitian jika hasil masing-masing responden dibandingkan dengan rata-ratanya, ternyata yang mendapatkan skor metode latihan $\left(\mathrm{X}_{3}\right)$, di atas rata-rata kelompok sebanyak 12 orang (21,82\%), di bawah rata-rata kelompok sebanyak 29 orang (52,73\%), dan hanya 14 orang (25,45\%) berada pada rata-rata kelompok.

\section{Hasil Pengujian Hipotesis}

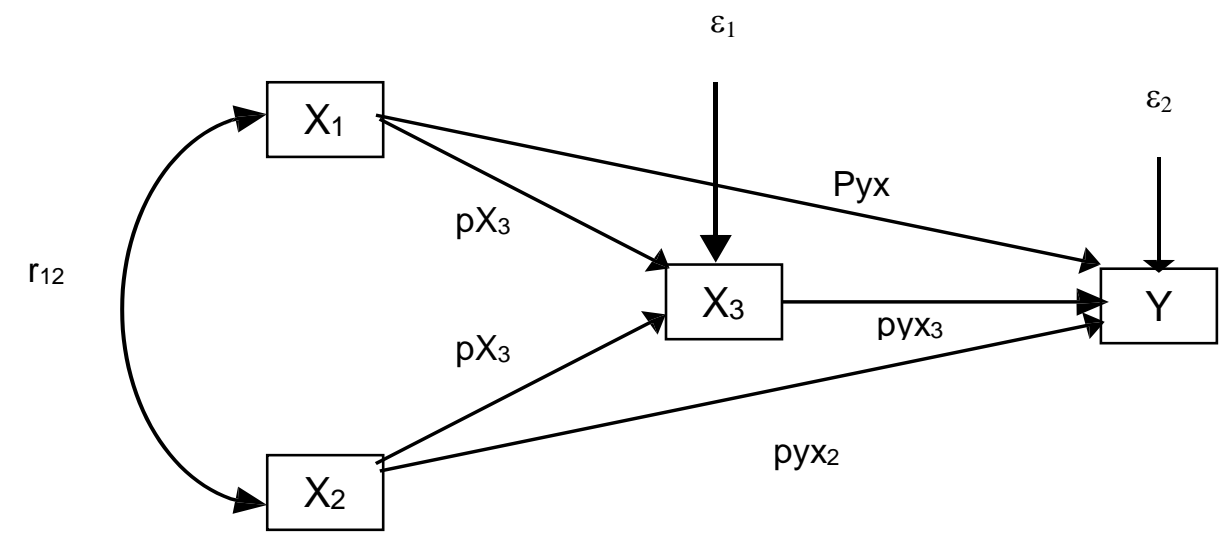

Gambar 2 : Model persamaan struktural dari penelitian 
Keterangan

$\mathrm{X}_{1}$ : Pemahaman Pelatih, $\mathrm{X}_{2}$ : Sarana dan Prasarana Olahraga

$\mathrm{X}_{3} \quad$ : Metode Latihan, $\mathrm{Y}$ : Cedera Olahraga

$\mathrm{r}_{12} \quad$ : Koefisien Korelasi, $\square, \square$ : Error

$\mathrm{pX}_{3} \mathrm{X}_{1}, \mathrm{pX}_{3} \mathrm{X}_{2}, \mathrm{pYX}_{3}, \mathrm{pYX}_{1}, \mathrm{pYX}_{2}$ : Koefisien Persamaan Struktural

\section{Pengujian Hipotesis Sub Struktur I}

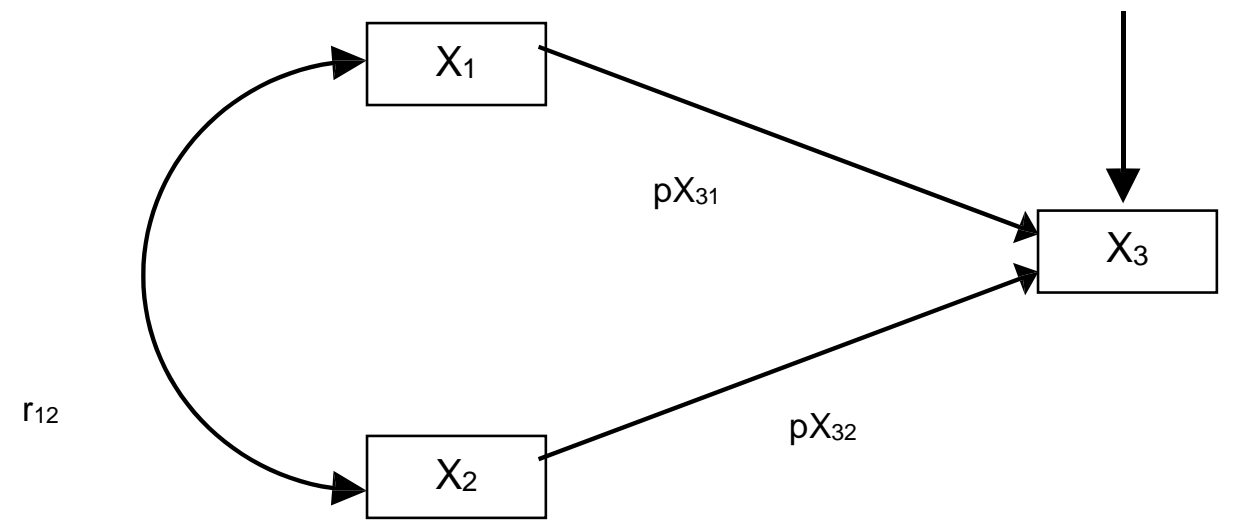

Gambar 3 : Hipotetik Sub Struktur 1

a. Uji Hipotesis Secara Keseluruhan Model 1 Sub Struktur I

Tabel 6. Analisis Varians Sub Struktur I

ANOVA

\begin{tabular}{|ll|c|c|c|c|c|}
\hline \multicolumn{2}{|l|}{ Model } & $\begin{array}{c}\text { Sum of } \\
\text { Squares }\end{array}$ & Df & $\begin{array}{c}\text { Mean } \\
\text { Square }\end{array}$ & F & Sig. \\
\hline 1 & Regression & 3957.785 & 2 & 1978.892 & 75.777 & $.000^{\mathrm{a}}$ \\
& Residual & 1357.961 & 52 & 26.115 & & \\
Total & 5315.745 & 54 & & & \\
\hline
\end{tabular}

a. Predictors: (Constant), VAR $\mathrm{X}_{2}, \mathrm{X}_{1}$

b. Dependent Variable: $\mathrm{X}_{3}$ 
Dari tabel analisis varians di atas diperoleh nilai $\mathrm{F}$ sebesar 75.77 dengan signifikansi 0,000. Karena nilai signifikansi kurang dari 0,05 maka dapat diambil keputusan tolak $\mathrm{H}_{0}$. Artinya terdapat pengaruh yang signifikan pemahaman pelatih dan sarana/prasarana olahraga secara bersama-sama terhadap metode latihan

\section{b. Uji Hipotesis Individual Sub Struktur I}

\section{Tabel 7 . Koefisien Sub Struktur I \\ Coefficients $^{\mathrm{a}}$}

\begin{tabular}{|c|c|c|c|c|c|c|}
\hline & \multirow[b]{2}{*}{ Model } & \multicolumn{2}{|c|}{$\begin{array}{c}\text { Unstandardized } \\
\text { Coefficients }\end{array}$} & \multirow{2}{*}{\begin{tabular}{|c|}
$\begin{array}{r}\text { Standardized } \\
\text { Coefficients }\end{array}$ \\
Beta
\end{tabular}} & \multirow[b]{2}{*}{$\mathrm{t}$} & \multirow[b]{2}{*}{ Sig. } \\
\hline & & B & Std. Error & & & \\
\hline \multirow[t]{3}{*}{1} & (Constant) & -14.050 & 7.860 & & -1.787 & .080 \\
\hline & $\begin{array}{c}\text { VAR0000 } \\
1\end{array}$ & .422 & .081 & .456 & 5.204 & .000 \\
\hline & $\begin{array}{c}\text { VAR0000 } \\
2\end{array}$ & .459 & .079 & .508 & 5.799 & .000 \\
\hline
\end{tabular}

a. Dependent Variable: VAR $\mathrm{X}_{3}$

Pengujian hipotesis individual dilakukan untuk setiap koefisien persamaan struktural dengan menggunakan uji t. Dari tabel koefisien sub struktur 1 di atas diperoleh nilai koefisien persamaan struktural untuk pemahaman pelatih sebesar 0.456 dan nilai t sebesar 5.204 dengan signifikansi 0.000 . Karena nilai signifikansi kurang dari 0,05 maka dapat diambil keputusan tolak $\mathrm{H}_{0}$. Artinya terdapat pengaruh yang signifikan positif pemahaman pelatih terhadap metode latihan.

Sedangkan nilai koefisien persamaan struktural untuk sarana/ prasarana sebesar 0.508 dan nilai t sebesar 5.799 dengan signifikansi 0.000 . Karena nilai signifikansi kurang dari 0,05 maka dapat diambil keputusan tolak $\mathrm{H}_{0}$. Artinya terdapat pengaruh yang signifikan positif sarana/prasarana olahraga terhadap metode latihan. 


\section{Pengujian Hipotesis Sub Struktur II}

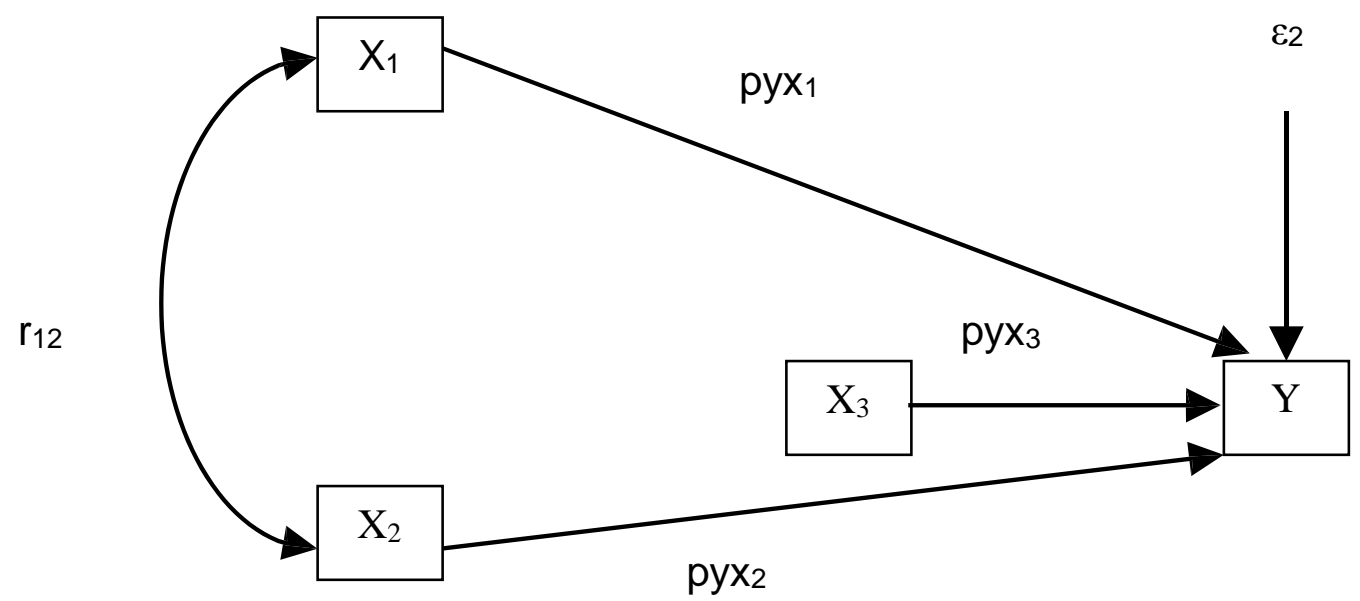

Gambar 4 : Hipotetik Sub Struktur 2

a. Uji Hipotesis Secara Keseluruhan Model 1 Sub Struktur II

Tabel 8. Analisis Varians Model 1 Sub Struktur II ANOVA $^{b}$

\begin{tabular}{|rl|r|r|r|r|r|}
\hline \multicolumn{2}{|l|}{ Model } & \multicolumn{1}{c|}{$\begin{array}{l}\text { Sum of } \\
\text { Squares }\end{array}$} & Df & Mean Square & F & \multicolumn{1}{c|}{ Sig. } \\
\hline 1 & Regression & 89333.458 & 3 & 29777.819 & 37.181 & $.000^{\mathrm{a}}$ \\
& Residual & 40845.524 & 51 & 800.893 & & \\
& Total & 130178.982 & 54 & & & \\
\hline
\end{tabular}

a. Predictors: (Constant), VAR $\mathrm{X}_{3}, \mathrm{VAR} \mathrm{X}_{1}, \mathrm{VAR} \mathrm{X}_{2}$

b. Dependent Variable: Y

Dari tabel analisis varians di atas diperoleh nilai F sebesar 37.181 dengan signifikansi 0,000. Karena nilai signifikansi kurang dari 0,05 maka dapat diambil keputusan tolak $\mathrm{H}_{0}$. Artinya terdapat pengaruh yang signifikan pemahaman pelatih 
sarana/prasarana olahraga dan metode latihan secara bersama-sama terhadap cedera olahraga. Dengan demikian model persamaan struktural secara keseluruhan dapat diterima, dan dapat dilanjutkan ke uji masing variabel bebas.

\section{b. Uji Hipotesis Individual Model 1 Sub Struktur II}

Tabel 9 . Koefisien Model 1 Sub Struktur II

Coefficients $^{\mathrm{a}}$

\begin{tabular}{|c|c|c|c|c|c|c|}
\hline & \multirow[b]{2}{*}{ Model } & \multicolumn{2}{|c|}{$\begin{array}{c}\text { Unstandardized } \\
\text { Coefficients }\end{array}$} & \multirow{2}{*}{$\begin{array}{l}\text { Standardized } \\
\text { Coefficients } \\
\text { Beta }\end{array}$} & \multirow[b]{2}{*}{$\mathrm{t}$} & \multirow[b]{2}{*}{ Sig. } \\
\hline & & B & Std. Error & & & \\
\hline \multirow[t]{4}{*}{1} & (Constant) & 493.186 & 44.846 & & 10.997 & .000 \\
\hline & VAR00001 & -.369 & .554 & -.080 & -.665 & .509 \\
\hline & VAR00002 & .385 & .562 & .086 & .685 & .497 \\
\hline & VAR00003 & -4.113 & .768 & -.831 & -5.356 & .000 \\
\hline
\end{tabular}

a. Dependent Variable: Y

Pengujian hipotesis individual dilakukan untuk setiap koefisien persamaan struktural dengan menggunakan uji t. Dari tabel koefisien model 1 sub struktur II di atas diperoleh nilai koefisien persamaan struktural untuk pemahaman pelatih sebesar -0.080 dan nilai t sebesar -0.665 dengan signifikansi 0.509. Karena nilai signifikansi lebih besar dari 0,05 maka dapat diambil keputusan terima $\mathrm{H}_{0}$. Artinya tidak terdapat pengaruh yang signifikan pemahaman pelatih terhadap cedera olahraga . Koefisien Sarana/prasarana olahraga sebesar 0.086 dan nilai t sebesar 0.685 dengan signifikansi 0.497. Karena nilai signifikansi lebih besar dari 0,05 maka dapat diambil keputusan terima $\mathrm{H}_{0}$. Artinya tidak terdapat pengaruh yang signifikan sarana/prasarana olahraga terhadap cedera olahraga. Sedangkan nilai koefisien persamaan struktural untuk metode latihan sebesar -5.356 dengan signifikansi 0.000. Karena nilai signifikansi kurang dari 0,05 maka dapat diambil keputusan tolak $\mathrm{H}_{0}$. Artinya terdapat pengaruh yang signifikan metode latihan terhadap cedera olahraga yang terjadi pada atlet 
Pelatda 2009-2012.

Dengan demikian model persamaan struktural model 1 sub struktur 1 dan sub struktur 2 belum dapat digunakan, karena variabel bebas pemahaman pelatih dan sarana/prasarana olahraga, keduanya tidak signifikan dan harus dikeluarkan dari persamaan struktural. Selanjutnya dilakukan analisis untuk model 2 sub struktur I dengan variabel bebas metode latihan yang diberikan kepada atlet Pelatda 2009-2012.

\section{c. Uji Hipotesis Individual Model 2 Sub Struktur II}

Tabel 10. Koefisien Model 2 Sub Struktur II Coefficients $^{\mathrm{a}}$

\begin{tabular}{|c|c|c|c|c|c|c|}
\hline \multirow{2}{*}{\multicolumn{2}{|c|}{ Model }} & \multicolumn{2}{|c|}{$\begin{array}{l}\text { Unstandardized } \\
\text { Coefficients }\end{array}$} & \multirow{2}{*}{$\begin{array}{c}\text { Standardized } \\
\text { Coefficients } \\
\text { Beta }\end{array}$} & \multirow[b]{2}{*}{$\mathrm{t}$} & \multirow[b]{2}{*}{ Sig. } \\
\hline & & B & Std. Error & & & \\
\hline \multirow[t]{2}{*}{1} & (Constant) & 108.921 & 2.617 & & 41.616 & .000 \\
\hline & VAR00003 & -.167 & .016 & -.825 & -10.630 & .000 \\
\hline
\end{tabular}

a. Dependent Variable: Y

Pengujian hipotesis dilakukan untuk setiap koefisien persamaan struktural dengan menggunakan uji t. Dari tabel koefisien model 2 sub struktur II di atas diperoleh nilai koefisien persamaan struktural untuk Metode Latihan sebesar -0,825 dan nilai t sebesar -10,630 dengan signifikansi 0,000. Karena nilai signifikansi kurang dari 0,05 maka dapat diambil keputusan tolak $\mathrm{H}_{0}$. Artinya terdapat pengaruh yang signifikan metode latihan terhadap cedera olahraga

\section{KESIMPULAN DAN SARAN}

Berdasarkan hasil diatas dapat disimpulkan sebagai berikut; 1. Terdapat pengaruh antara pemahaman pelatih terhadap metode latihan. 2. Terdapat pengaruh antara sarana/prasarana olahraga terhadap metode latihan. 3. Terdapat pengaruh antara metode latihan terhadap terjadinya cedera. 4. Tidak terdapat pengaruh 
langsung antara pemahaman pelatih terhadap terjadinya cedera olahraga. 5. Tidak terdapat pengaruh langsung antara sarana/prasarana oahraga terhadap terjadinya cedera olahraga. 6. Terdapat pengaruh antara pemahaman pelatih terhadap terjadinya cedera olahraga melalui metode latihan. 7. Terdapat pengaruh antara sarana/prasarana olahraga terhadap terjadinya cedera olahraga.

Kepada pimpinan KONI Provinsi DKI Jakarta dalam usaha menurunkan resiko cedera pada atlet perlu secara teratur mengadakan seminar dan workshop mengenai pencegahan- penanganan cedera, serta menyediakan sarana/prasarana olahraga yang memadai dan bagi kalangan akademisi dibidang kesehatan olahraga disarankan untuk melakukan penelitian lainnya dengan melibatkan variabel-variabel lain dari aspek kecabangan olahraga, pengaruh lingkungan, status gizi dan lainnya yang dapat menurunkan resiko cedera.

\section{DAFTAR PUSTAKA}

Abernethy, Bruce, et. al. 1991, Better Coaching, Advanced Coachs Manual, Canberra : Australian Coaching Council Incorporated.

Arikunto, S. 1999, Dasar-Dasar Evaluasi Pendidikan, Jakarta : Bumi Aksara. Bompa, Tudor O. 2009, “Periodization :Theory and Methodology of Training” . New York : Human Kinetic, 2009

Chaplin. JP . 2006, Kamus Lengkap Psikologi. Terjemahan. Jakarta : PT Raja Grafindo Persada.

Clenaghan. MC, Pate, Rotella. 1984, Scientific Foundation Of Coaching. Philadelphia : Saunders College Publishing.

FIFA. 2005, Football Medicine Manual. Hitzigweg Zurich. F-Marc.

Fleck J. Steven, William J. Kraemer. 1996, Periodization Breakthrough.The Ultimate Training System, New York : Advanced research Press, Inc. Fried. Gil, 2005. Managing Sport Facilities, New York : Human Kinetics. 
Hardianto Wibowo, 2008. Pencegahan Dan Penatalaksanaan Cedera Olahraga . Jakarta : EGC.

I Made Putrawan, 1990 . Pengujian Hipotesis Dalam Penelitian-Penelitian Sosial. Jakarta : Rineka Cipta.

International Olympic Committee, 2000. Medical Commission Sport Medicine Manual.

Morris F. Alfred, 1984. Sports Medicine, Prevention of Athletic Injuries. New York: Wm. C. Brown Publisher.

Naga S. Dali, 1992. Pengantar Teori Skor Pada Pengukuran Pendidikan Jakarta : Besbats.

Nazir, Moh, 2003. Metoda Penelitian. Jakarta : Ghalia.

Nossek. Josef, 1982. General Theory of Training, Lagos : Pan African Press ltd.

P. Brukner. , Khan K, et al., 2007. CInical Sport Medicine. $3^{\text {rd }}$ ed. Canberra: McGraw Hill.

Publow, Barry, 1999. Speed on Skates. New York : Human Kinetics.

Riduwan, Engkos Achmad Kuncoro, 2008. Cara Menggunakan Dan Memaknai Analisis Jalur Path Analysis . Bandung : Alfabeta

Shihab Helmi Rukmini, 1995. “Pencegahan Cedera Olahraga”. Majalah Kesehatan FKUI, th.XI. No. 3.

Suharsimi, Arikunto, 1998. Prosedur Penelitian Suatu Pendekatan Praktek. Jakarta: PT Rineka Cipta.

Supartono, 2000. Sarana Dan Prasarana Olahraga. Jakarta: Departemen Pendidikan Nasional.

Tim Peneliti FIK-UNJ, 2005. Konsultasi Standarisasi Sarana Dan Prasarana Olahraga. Jakarta. 